\title{
The Shelf Life and Recommended Dietary Allowances (RDA) Analysis of Cassava (Manihot esculenta Crantz) Flakes Enriched with Bean Flour (Phaseolus vulgaris L.)
}

\author{
Eka Herlina, Farida Nuraeni, Mira Miranti
}

\begin{abstract}
Food processing in commercial industry generally aims to extend shelf life, change or increase products' characteristics (color, flavor, texture), ease treatment and distribution, increase economic value, and maintain or improve quality, particularly nutritional quality, digestibility, and nutritional value. The objective of this research is to determine the shelf life of products made from cassava flour which is fortified by red bean flour, and to understand whether there is a decrease in nutritional value during the storage period, as well as to calculate the Recommended Dietary Allowances (RDA).

The Recommended Dietary Allowances of Cassava Flakes with Red Bean Flour for breakfast has a very important function. For instance, children who are in school need plenty of energy to start their activities and stay focused at school. Breakfast food needs to fulfill the 20-25\% of the RDA for children, who need a total of 2,000 kilo calories per day. An alternative option for breakfast is nutritious flakes that can be consumed with a quick preparation time.

The method to determine the shelf life is carried out using the Accelerated Self Life Testing (ASLT) and critical water activity methods, whereas to determine the proximate nutritional value we used the gravimetric method to determine the ash content and water content. In addition, we used the Kjehdahl method to determine the protein content, the sokhlet method for the fat content, and by difference method for the carbohydrate content. The result obtained for the nutritional value throughout the storage period is that the nutritional value of the flakes decreased after being stored for 10 weeks. The result of determining the shelf life using a critical water activity method is 307.5 days of storage.
\end{abstract}

RDA or the Recommended Dietary Allowance is the percentage of the amount of a nutrient contained in the food consumed based on the daily needs of the healthy person. Generally this daily requirement is based on daily caloric requirement of $2000 \mathrm{kcal}$, but some also use base $2500 \mathrm{kcal}$. $R D A$ 's guidance in Indonesia can follow the guidance given by POM RI based on Decree of the Head of POM RI No. HK.00.05.52.6291 on Food Label Nutritional Reference.

Index Terms: Flakes, nutritional value, shelf life, proximate analysis, critical water activity method, RDA

Revised Manuscript Received on April 25, 2019.

Eka Herlina, Department of Chemistry, Faculty of Mathematics and Natural Sciences, PakuanUniversity. Bogor,West Java.

Farida Nuraeni, Department of Chemistry, Faculty of Mathematics and Natural Sciences, PakuanUniversity. Bogor,West Java.

Mira Miranti, Department of Chemistry, Faculty of Mathematics and Natural Sciences, PakuanUniversity. Bogor,West Java.

\section{INTRODUCTION}

Flakes is a food that is usually eaten at breakfast with milk mixed. Flakes are generally made from cereals or corn now have another alternative that flakes made from cassava flour. To add protein and fiber in flakes, made of flour fortification with the addition of red beans. Food processing generally aim to extend shelf life, increase the economic value and improve or maintain the quality [1].

Before the food products reach the consumer, it will be through the storage process in advance that can cause loss of quality. Therefore we need specific treatments to the food product to extend the shelf life, one factor that is packaging [3]. Foodstuffs have yan properties vary in their susceptibility to uptake or release of gas (air and water vapor). Dry material should be protected from moisture absorption and oxygen by using packaging material that has low permeability to gas [8].

Shelf life estimation method can be done by the method of Self Accelerated Life Testing (ASLT) ie by storing food products in the environment that causes rapid deterioration, either in temperature or humidity conditions higher storage space. Acceleration method can be performed with a shorter time with good accuracy. ASLT method often used is Arhennius models and models of critical water content [4].

\section{PROCEDURE FOR PAPER SUBMISSION}

\section{A. Equipment and Materials}

The tools used are furnaces, ovens, pumpkin fat, pumpkin Kjehdahl, cup porcelain, a petri dish, buret and clamps, mortar and pestle, desiccator, beaker $(50 \mathrm{~mL}, 200 \mathrm{~mL}, 250$ $\mathrm{mL}, 500 \mathrm{~mL}$ ), analytical balance and tools Other glasses are required in the study. Flakes, selenium, concentrated $\mathrm{H} 2 \mathrm{SO} 4$, distilled water, $\mathrm{NaOH}, \mathrm{H} 3 \mathrm{BO} 3$, indicators (ciran methyl red and bromine creosol green), $\mathrm{HCl} 0.1 \mathrm{~N}$, solvent hexane, $\mathrm{NaCl}$ (RH 76), K2Cr2O7 (RH 98), KI (RH 69), KCl (RH 84), $\mathrm{NaOH}(\mathrm{RH} 7)$. 
The Shelf Life and Recommended Dietary Allowances (RDA) Analysis of Cassava (Manihot esculenta Crantz) Flakes Enriched with Bean Flour (Phaseolus vulgaris L.)

\section{B. Nutrient Content Test During Storage Periode}

Nutrient content analyzed periodically at room temperature for a week 0 , week 2 , week 4 , week 6 , week 8 , and week 10.

\section{1) Ash Content Test}

Using the gravimetric method with ashing samples in an electricfurnace for $4-6$ hours at a temperature of $400^{\circ} \mathrm{C}-600^{\circ}$ C. Cooled in a desiccator and weighed to constant weight $($ AOAC, 1995$)$. ash content $=($ ash mass $) /($ mass of sample $) \times$ $100 \%$

\section{2) Assay Test Water}

Oven emptied petri dish, then cooled and weighed empty weight. A number of flakes weighed (3-5 grams) put in a petri dish. Then put in a preheated oven at $105^{\circ} \mathrm{C}$. The sample is weighed on a regular basis to obtain a fixed weight (AOAC, 1995).

water content $=((a-b)) /(c) \times 100 \%$

description :

$\mathrm{a}=$ weight of the cup and the initial sample

$\mathrm{b}=$ weight of the cup and the final sample

$\mathrm{c}=$ weight of the initial sample

\section{3) Protein Assays}

Phase destruction: flakes weighed as much as 0.5 - 1 gram and then inserted into the flask Kjehdahl. 0:25 grams of selenium and $25 \mathrm{ml}$ of $\mathrm{H} 2 \mathrm{SO} 4$ was added to the flask. Flask is then inserted into a heater. Silakukan destruction process until the solution is clear green color. Phase distillation: destructed samples were poured into a distillation flask and then added $50 \mathrm{ml}$ of distilled water. Rinse water is also put into the distillation apparatus and $40 \% \mathrm{NaOH}$ is added to 20 $\mathrm{mL}$. The fluid in the tip of the condenser tube accommodated in the Erlenmeyer flask containing a solution of $\mathrm{H} 3 \mathrm{BO} 3$ and 2 drops of indicator (methyl redand green creosol bromine).Performed to obtain a bluish-green distillate. Phase titration:Titration done using $0.1 \mathrm{~N} \mathrm{HCl}$ solution until the color changes to pink. Titrant volume is read and recorded (AOAC, 1995).

$\% \mathrm{~N}=((\mathrm{ml} \mathrm{HCl}-\mathrm{ml} \mathrm{HCl}$ blank $) \times 14007 \times 0.1 \mathrm{~N} \mathrm{HCl}) /(\mathrm{mg}$ sample $) \times 100 \%$ Nitrogen levels of protein $=\% \mathrm{Nx} \mathrm{6:25}$

\section{4) Assay Fat}

Flask used dried and roasted at $105^{\circ} \mathrm{C}$, then cooled in a desiccator. Once cool, weighed empty weight. Flakes weighed as much as 3 grams, wrapped in filter paper and put into the extraction tool (sokhlet) which already contains the solvent hexane. Soxhletation process is carried out until a clear solution and a solvent that is in the fat pumpkin distilled. Furthermore, fat pumpkin contains the results of extraction is heated in a preheated oven at $105^{\circ} \mathrm{C}$ until its weight is constant, cooled in a desiccator and weighed (AOAC, 1995).
Fat content $=($ fat weight $) /($ weight of sample $) \times 100 \%$

5) Determination of Levels of Carbohydrates (AOAC, 1995).

Using the methodbydifference, carbohydrate levelscan be determinedformula

$\%$ Carbohydrates $=100-(\mathrm{P}+\mathrm{KA}+\mathrm{A}+\mathrm{L})$

Description :

$\mathrm{P}=$ Protein content $\mathrm{KA}=$ Water content

A $=$ Ash content

$\mathrm{L}=$ Fat content

Food Shelf Life Estimation with Critical Water ASLT Method

\section{6) Determination of Initial Moisture Content (Mo)}

Initial moisture content was analyzed by the oven method (AOAC, 1995). Initial moisture content expressed in dry weight ( $\%$ bk). Results of the analysis of the initial moisture content will be used as a correction factor in determining the weight of solids (Ws) of samples required in the calculation of the equation Labuza shelf life.

\section{Determination of Critical Water Content}

Determination of the critical water content is done by storing products in containers that have high humidity (Labuza et al., 1985) and organoleptic testing periodically. Products are stored in a container or chamber with a saturated salt solution is $\mathrm{NaCl}$ which has a value of $\mathrm{RH}$ 76 . Observations were conducted periodically every 24 hours. After the rejection of the products specified limit, then carried out a critical analysis of water content. Analysis of the critical water content is done using the oven method (AOAC, 1995 ) and expressed in dry weight (\% bk).

\section{1) Determination of sorption isotherm curve}

Sample preparation is done saturated salt solution. Then weighed amount of salt and put in a container or chamber. The salt is then stirred and added some water to maintain saturation of the solution so that the resulting relative humidity remains and does not interfere with the process of sorption. Chambers then covered and left for 24 hours in a constant temperature.

Table 1. Number Salt and Water Preparation Salt Saturated Solution

\begin{tabular}{|l|l|l|l|}
\hline Type Salt & RH (\%) & Quantity Salt(g) & Water(mL) \\
\hline $\mathrm{NaOH}$ & 7 & 150 & 85 \\
\hline $\mathrm{KI}$ & 69 & 200 & 50 \\
\hline $\mathrm{KCl}$ & 84 & 200 & 80 \\
\hline $\begin{array}{l}\mathrm{K} 2 \mathrm{Cr} 2 \mathrm{O} \\
7\end{array}$ & 98 & 100 & 100 \\
\hline
\end{tabular}

Sumber : Agus (2004) 
Flakes taken 5 grams then put into a glass measure or small. Then inserted into the chambers which already contains some saturated salt solution. The sample is weighed periodically to obtain a fixed weight. Then calculate the moisture content

\section{2) Determination of Shelf Life}

Shelf life calculation equation determined Labuza modified as follows (Labuza, 1982)

\section{Description :}

$\Theta=$ time to reach the critical moisture content or shelf life (days)

Mo $=$ moisture content of the product at the beginning of storage $(\% \mathrm{bk})$

$\mathrm{Mc}=$ critical moisture content at a specific temperature $(\%$ bk)

$\mathrm{Me}=$ equilibrium moisture content $(\% \mathrm{db})$

$\mathrm{k} / \mathrm{x}=$ permeability of packaging $(\mathrm{g} / \mathrm{m} 2$.day $\mathrm{mmhHg})$

$\mathrm{A}=$ area of the packaging which is calculated based on the dimensions of packaging used $(\mathrm{m} 2)$

$\mathrm{Ws}=$ weight of initial product solids $(\mathrm{g})$

Po = saturated vapor pressure $(\mathrm{mmHg})$

$\mathrm{b}=$ slope of the curve isotherm

RDA or the Recommended Dietary Allowance is the percentage of the amount of a nutrient contained in the food consumed based on the daily needs of the healthy person. Generally this daily requirement is based on daily caloric requirement of $2000 \mathrm{kcal}$, but some also use base $2500 \mathrm{kcal}$. RDA's guidance in Indonesia can follow the guidance given by POM RI based on Decree of the Head of POM RI No. HK.00.05.52.6291 on Food Label Nutritional Reference. Other countries such as the United States through the FDA also.

\section{RESULT AND DISCUSSION}

\section{A. Nutrient Content Stability}

In the stability test, namely the test nutrient content of fat, carbohydrates, moisture content, ash content, and protein assay results obtained as well as table stability for 10 weeks (Table 2). Water activity turned out to affect the stability and durability of food. The increase in water levels caused by different environmental conditions, such as storage and temperature (Kusnandar, 2010). The water content during the storage period indicated increasingly rising every week. This water activity causes a decrease in other elements. The levels of protein, fat and carbohydrate levels keminggunya week decreases with increases in water content.

\section{B. The Flakes Shelf Life}

The shelf life is determined by using accelerated method to approach the critical moisture content. The shelf life is calculated by an equation Labuza (1982) is a storage shelf life at $76 \% \mathrm{RH}$. Based on this equation obtained several factors and parameters of initial moisture content (Mo), the water content of critical (Mc), the water content equilibrium (Me), constant water vapor permeability of packaging $(\mathrm{k} / \mathrm{x})$, the ratio of the packaging with the dry weight of the product (A / Ws), saturated water vapor pressure at storage conditions (Po), and the slope of the curve of sorption isotherms (b).Initial moisture content obtained is $0.0330 \mathrm{~g} \mathrm{H} 2 \mathrm{O} / \mathrm{g}$ solids. Critical water content obtained by the $0.1040 \mathrm{~g} \mathrm{H} 2 \mathrm{O}$. / $\mathrm{G}$ solids. The equilibrium moisture content is $0.2163 \mathrm{~g} \mathrm{H} 2 \mathrm{O}$ / $\mathrm{g}$ solids. This is obtained by the sorption isotherm curve.

Based on the chart below, the value of the slope on the curve sorption isotherm flakes product is 0.136 . Estimation of shelf life trials flakes based methods ASLT according Labuza approach to critical water content, obtained several supporting factors and parameters as listed in Table 4. Source: Primary Data Research (2015) and Labuza (1982)

The value obtained is then put into the equation Labuza (1982)

$$
\theta=\frac{\ln \frac{(M e-M i)}{(M e-M c)}}{\frac{k}{x}\left(\frac{A}{W s}\right) \frac{P o}{b}}
$$$$
\theta=\frac{\ln \frac{(0.21636-0.0330)}{(0.21636-0.1040)}}{0.0136\left(\frac{0.02535}{50}\right) \frac{31.924}{0.136}}
$$$$
\theta=\frac{\ln \frac{(0.19336)}{(0.11236)}}{0.0136(0.0005)(234)}
$$

$$
\theta=\frac{\ln 1.6312}{0.0015912}
$$

$\theta=307.5$ hari

Table 2. Nutrient Content Data storage for 10 weeks

\begin{tabular}{l|cccccc}
\hline \multirow{2}{*}{ Test } & \multicolumn{6}{|c}{ Week (content \%) } \\
\cline { 2 - 7 } & 0 & 2 & 4 & 6 & 8 & 10 \\
\hline Water & 3.31 & 5.3 & 7.2 & 7.6 & 7.7 & 7.94 \\
Ash & 3.23 & 3.15 & 3.12 & 3.12 & 3.1 & 3.1 \\
Fat & 4.85 & 4.8 & 4.75 & 4.73 & 4.71 & 4.7 \\
Protein & 9.94 & 9.93 & 9.87 & 9.84 & 9.8 & 9.75 \\
Karbohidrat & 78.9 & 77 & 75.1 & 74.7 & 74.54 & 74.34 \\
\hline
\end{tabular}


The Shelf Life and Recommended Dietary Allowances (RDA) Analysis of Cassava (Manihot esculenta Crantz) Flakes Enriched with Bean Flour (Phaseolus vulgaris L.)

Table 3. Water Content Equilibrium Flakes andTime Achievement In some RH Storage. Salt $\mathrm{RH}(\%)$ Aw (RH / 100) KA Equ

\begin{tabular}{lllll}
\hline Salt & RH & $\begin{array}{l}\text { Aw } \\
(\mathrm{RH} / 100)\end{array}$ & $\begin{array}{l}\text { KA } \\
\text { Equilibrium(g } \\
\mathrm{H}_{2} \mathrm{O} / \mathrm{g} \text { solid) }\end{array}$ & $\begin{array}{l}\text { Time } \\
\text { (day) }\end{array}$ \\
\hline $\mathrm{NaOH}$ & 7 & 0.07 & 0.1325 & 18 \\
$\mathrm{Kl}$ & 69 & 0.69 & 0.1830 & 25 \\
$\mathrm{KCl}$ & 84 & 0.84 & 0.2220 & 14 \\
$\mathrm{~K}_{2} \mathrm{Cr}_{2}$ & 98 & 0.98 & 0.2704 & 4 \\
$\mathrm{O}_{7}$ & & & & 4 \\
\hline
\end{tabular}

Table 4.Parameter Value of Calculation Shelf Life Flakes

\begin{tabular}{|l|l|}
\hline Parameter & Value \\
\hline $\mathrm{RH}(\%)$ & 76 \\
\hline $\mathrm{Aw}$ & 0.76 \\
\hline KA initial (Mi) (g H2O / g solids) & 0.0330 \\
\hline Critical KA (Mc) (g H2O / gsolids) & 0.1040 \\
\hline Sorption isotherm curve slope (b) & 0.136 \\
\hline $\begin{array}{l}\text { A Equilibrium (Me) (g H2O / g } \\
\text { solids) }\end{array}$ & 0.21636 \\
\hline $\begin{array}{l}\text { Packaging permeability (k / x) (g / } \\
\text { m2.day.mmHg) }\end{array}$ & 0.0136 \\
\hline Size Packaging (A) (m2) & 0.02535 \\
\hline Solids weight per package (Ws)(g) & 50 \\
\hline $\begin{array}{l}\text { Saturated vapor pressure } \\
\text { temperature of 30 C (Po)(mmHg) }\end{array}$ & 31,824 \\
\hline
\end{tabular}

Sorptionsigmoidcurveshaperesembles the letterS, though nt perfect.

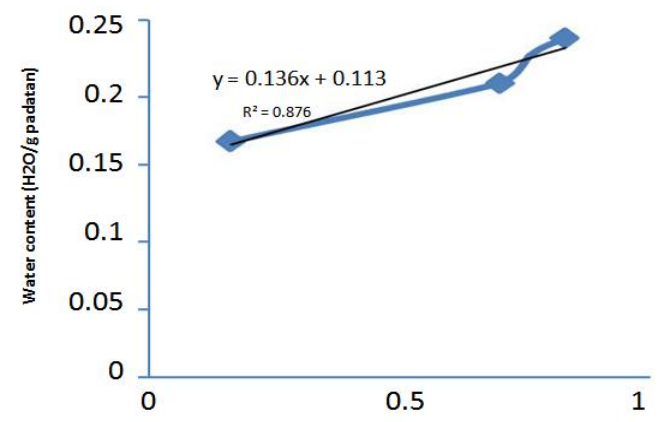

\section{CONCLUSION}

Based on the results of further research flakes products made from cassava flour fortification red bean flour can be concluded that:

1. Nutrient flakes during storage changes. These changes are caused bythe increase in moisture content during storage. The high water content causes changes in the content of diminishing and durability are reduced.

2. Based on the method Labuza(1982) approach to estimate the critical water content of the shelf life of a product, resulting value of the product shelf life flakes up to 307 days.

3. Rough calculations of the selected formulation $\mathrm{AKG}$

Flakes (3:2) /100 g Energy $314.96 \mathrm{kcal}$, Carbohydrate $51.17 \mathrm{~g}$, Protein 5.16 g, Fat 9.96 g, Vitamin A 166.05 IU, Vitamin C 0.51 $\mathrm{mg}$, Vitamin $\mathrm{E}<0.01 \mathrm{mg}$.

\section{REFERENCES}

1. N. Andarwulan, and P. Hariyadi, "Perubahan Mutu (Fisik, Kimia, Mikrobiologi) Produk Pangan Selama Pengolahan dan penyimpanan Produk Pangan.” Pelatihan Pendugaan Waktu Kadaluwarsa (Self Life), Bogor, 1-2 Desember 2004.

2. AOAC., "Official Methode of Analysis of The Association of Analytical Chemists," Washingtong D.C., 1995.

3. Farid, A. Rakhmat, S. Hadi, K. A. Eka, "Sifat Fisiko Kimia Pada Pengemasan dan Penyimpanan Cassava Flakes Fortifikasi", Jurnal Teknologi Pertanian, 2009, 4(2): 48-55.

4. L. R. Gordon, "Food Packaging and Shelf Life", Australia: CRC Press.

5. F. Kusnandar, D.R. Adawiyah, dan M. Fitria, "Pendugaan Umur Simpan Produk Biskuit dengan Metode Akselerasi berdasarkan Pendekatan Kadar Air Kritis", Jurnal Teknologi dan Industri Pangan XXI , 2010, (2): 117-122.

6. T.P. Labuza, "Shelf Life Dating of Foods". Westport, Connecticut: Food and Nutrition Press. Inc, 1982.

7. T.P. Labuza, M.K. Schimdl, "Accelerated Shelf Life Testing of Foods", Food Technology, 1985, 39(9): 57-62, 64,134.

8. H. Purnomo, "Aktivitas Air dan Peranannya dalam Pengawetan Pangan", Jakarta: Penerbit Universitas Indonesia, 1995.

9. A. Supriadi, "Optimasi Teknologi Pengolahan Kajian Sorpsi Isothernmik Beras Jagung Instan”, Tesis. Sekolah Pascasarjana IPB. Bogor. 2004. 